\title{
Drying and essential oil extraction of Brazilian peppertree (Schinus terebinthifolius Raddi) fruits
}

\author{
Julia L. Governici ${ }^{1}$, Naiara C. Z. Sperotto ${ }^{1}$, Evandro de C. Melo ${ }^{1}$, Diego A. Gonzaga ${ }^{1}$ \& \\ Antônio P. S. Carneiro ${ }^{2}$
}

${ }^{1}$ Universidade Federal de Viçosa/Departamento de Engenharia Agrícola, Viçosa, MG, Brasil. E-mail: julia.governici@gmail.com (Corresponding author) - ORCID: 0000-0002-6129-4626; naiazotti@gmail.com - ORCID: 0000-0003-4536-6850; evandro.cm@gmail.com - ORCID: 0000-0002-1418-8345; gonzagaaugusto@gmail.com - ORCID: 0000-0001-6242-3453

${ }^{2}$ Universidade Federal de Viçosa/Departamento de Estatística, Viçosa, MG, Brasil. E-mail: policarpo@ufv.br - ORCID: 0000-0002-9043-3242

\begin{abstract}
The objectives of this work were to determine the effect of the drying air temperature and fruit fragmentation on the essential oil yield of Brazilian peppertree (Schinus terebinthifolius) fruits, to model drying curves, and evaluate the energy consumption of the drying process. The study was conducted in Viçosa, MG, Brazil, in May 2018. The experiment was conducted using a completely randomized design, in a $3 \times 2$ factorial arrangement ( 3 drying air temperatures and 2 fruit fragmentation types), with three replications. Whole fruits $(350 \mathrm{~g})$ were dried at 50,60 , and $70^{\circ} \mathrm{C}$ until the water content reached a water content of 0.11 on dry basis; $90 \mathrm{~g}$ of these fruits where kept in the dryer until reaching an equilibrium water content for the modeling. The data of drying were fitted to 12 mathematical models, whose performances were evaluated by the coefficient of determination, mean relative error, mean estimated error, and residue distribution. The essential oil was extracted by hydro-distillation using whole or fragmented fruits. Fruits dried at $50^{\circ} \mathrm{C}$ and fragmented before extraction had higher essential oil yield. The use of air temperature of $70{ }^{\circ} \mathrm{C}$ resulted in lower drying time and energy consumption. The data fitted to the Midilli model satisfactorily, regardless of the drying air temperature.
\end{abstract}

Key words: medicinal plant, post-harvest, mathematical modeling, temperature, fruit fragmentation

\section{Secagem e extração de óleo essencial de pimenta-rosa (Schinus terebinthifolius Raddi)}

\begin{abstract}
RESUMO: Objetivou-se determinar a influência da temperatura do ar de secagem e da fragmentação dos frutos no rendimento de óleo essencial de pimenta-rosa (Schinus terebinthifolius), ajustar as curvas de secagem e avaliar o consumo energético do processo. O estudo foi conduzido em Viçosa, MG, em maio de 2018. Realizou-se o experimento no delineamento inteiramente casualizado e esquema fatorial 3 x 2 (três temperaturas de secagem e dois tipos de fragmentação do fruto), com três repetições. Foram secos $350 \mathrm{~g}$ de frutos inteiros a $50,60 \mathrm{e} 70^{\circ} \mathrm{C}$ até atingir teor de água de 0,11 base seca. Para modelagem, $90 \mathrm{~g}$ permaneceram no secador até atingir teor de água de equilíbrio. Os dados experimentais de secagem foram utilizados para ajustar 12 modelos matemáticos, cujos desempenhos foram avaliados pelo coeficiente de determinação, erro médio relativo, erro médio estimado e distribuição de resíduos. Após a secagem, extraiu-se o óleo essencial por hidrodestilação com os frutos inteiros ou triturados. Frutos secos a $50^{\circ} \mathrm{C}$ e triturados antes da extração tiveram maior rendimento de óleo essencial. A temperatura de $70{ }^{\circ} \mathrm{C}$ apresentou menor tempo de secagem e consumo energético. O modelo de Midilli se ajustou satisfatoriamente aos dados, independente da temperatura de secagem.
\end{abstract}

Palavras-chave: planta medicinal, pós-colheita, modelagem matemática, temperatura, fragmentação do fruto 


\section{INTRODUCTION}

Schinus terebinthifolius Raddi (Brazilian peppertree) is a plant species native to Brazil, locally known as 'aroeira-vermelha'. Its fruits are rich in essential oil and phenolic compounds, and their therapeutic properties had been confirmed in several studies (Rosas et al., 2015; Dannenberg et al., 2016).

Fruits of this plant should be dried after harvest to ensure their conservation and preserve their chemical compounds. The drying, in this case, is a complex process due to the characteristics of this plant and water transport phenomena involved, which also affect the drying rate. Thus, mathematical modeling and simulations can be used to overcame this complexity and obtain adequate operational conditions (Castro et al., 2018).

This process can represent up to $40 \%$ of the energy consumption required by the industry (Mujumdar \& Devahastin, 2000). Increasing the drying air temperature can affect the drying rate and time (Silva et al., 2015) and, consequently, the energy consumption and operational costs. However, a continuous high-temperature air supply can cause structural and physico-chemical changes in the plant part used (Borsato et al., 2008; Gasparin et al., 2014).

In addition, essential oil yield and chemical composition are also affected by the extraction method (Memarzadeh et al., 2015), and the plant part used (Cavalcanti et al., 2015) and fragmentation (Rosado et al., 2011). The fragmentation can increase yield of extraction of compounds of interest due to the larger contact surface area (Vinatoru, 2001).

In this context, the objectives of this study were to determine the effect of the drying air temperature and fruit fragmentation on the essential oil yield of Brazilian peppertree fruits, to model drying curves, and to evaluate the energy consumption of the drying process.

\section{Material ANd Methods}

The experiment was conducted using a completely randomized design in a $3 \times 2$ factorial arrangement, with three replications, totaling 18 experimental units. The factors consisted of 3 drying air temperatures $\left(50,60\right.$, and $70{ }^{\circ} \mathrm{C}$ ) and 2 fruit fragmentation types before the extraction of the essential oil (dried whole fruits, and fragmented fruits in a knife mill after drying).

The Brazilian peppertree (Schinus terebinthifolius Raddi) fruits were collected in São Mateus, ES, Brazil, provided by the AgroRosa company (18 $43^{\prime} 5^{\prime \prime} \mathrm{S}$, and $39^{\circ} 51^{\prime} 26^{\prime \prime} \mathrm{W}$, and altitude of $37 \mathrm{~m}$ ). The samples were placed in plastic containers and taken to Viçosa, MG, Brazil, in May 2018. The fruits were cleaned, homogenized, and stored in a BOD (Biochemical Oxygen Demand) chamber at $3.5^{\circ} \mathrm{C}$ until the drying. The initial content of water in fruit was 0.62 on dry basis (d.b.), which was determined using $10 \mathrm{~g}$ of fruits dried in a forced-air circulation oven at $105 \pm 2{ }^{\circ} \mathrm{C}$ until constant weight (ANVISA, 2010).

The fruits were dried at the Medicinal Plant Drying Laboratory of the Universidade Federal de Viçosa, in Viçosa, MG, Brazil; $350 \mathrm{~g}$ of fresh whole fruits were subjected to continuous drying in an electric dryer with air temperatures of 50,60 and $70{ }^{\circ} \mathrm{C}$ and air speed of $2.0 \mathrm{~m} \mathrm{~s}^{-1}$. The mean environmental air temperature and relative humidity were $22.9^{\circ} \mathrm{C}$ and $65.8 \%$, respectively; they were determined using a digital thermohydrometer (HOBO datalogger, Onset) and the drying air relative humidity was determined using the GRAPSI $7.0^{\circ}$ program (Melo et al., 2004), considering a constant mix ratio during the warming.

The samples were weighed every $5 \mathrm{~min}$ and the drying ended when the water content reached 0.11 d.b. (Gasparin et al., 2014; 2017). However, $90 \mathrm{~g}$ of fruits were kept in the dryer for the mathematical modeling, forming a thin layer until an equilibrium water content was reached. The hygroscopic equilibrium occurred when three consecutive weights had no variation. The water content ratio (RX) was calculated during the drying for the different temperatures using Eq. 1:

$$
\mathrm{RX}=\frac{\mathrm{X}-\mathrm{X}_{\mathrm{e}}}{\mathrm{X}_{\mathrm{i}}-\mathrm{X}_{\mathrm{e}}}
$$

where:

RX - water content ratio, dimensionless;

$\mathrm{X}$ - product water content at weighing time, decimal, d.b.;

$\mathrm{X}_{\mathrm{i}}$ - product initial water content, decimal, d.b.; and,

$\mathrm{X}_{\mathrm{e}}$ - product equilibrium water content, decimal, d.b..

The drying rate, product water evaporated per unit of dry matter (d.m.) per unit of time, was estimated at every weighing using Eq. 2 (Park et al., 2007):

$$
\mathrm{DR}=\frac{\mathrm{X}_{0}-\mathrm{X}_{\mathrm{i}}}{\Delta \mathrm{T}}
$$

where:

DR - drying rate, $\mathrm{kg}$ water $\mathrm{kg}^{-1}$ d.m.h $\mathrm{h}^{-1}$;

$\mathrm{X}_{0} \quad$ - product water content in the previous weighing, decimal, d.b.;

$\mathrm{X}_{\mathrm{i}}$ - product water content in the current weighing, decimal, d.b.; and,

$\Delta \mathrm{T}$ - time interval between weighing, $\mathrm{h}$.

The drying data were fitted to 12 mathematical models (Eq. 3 to 14) used in the description of drying of agricultural products (Table 1).

Table 1. Non-linear regression models used to predict the drying phenomenon in the thin layer formed from whole fruits of Brazilian peppertree

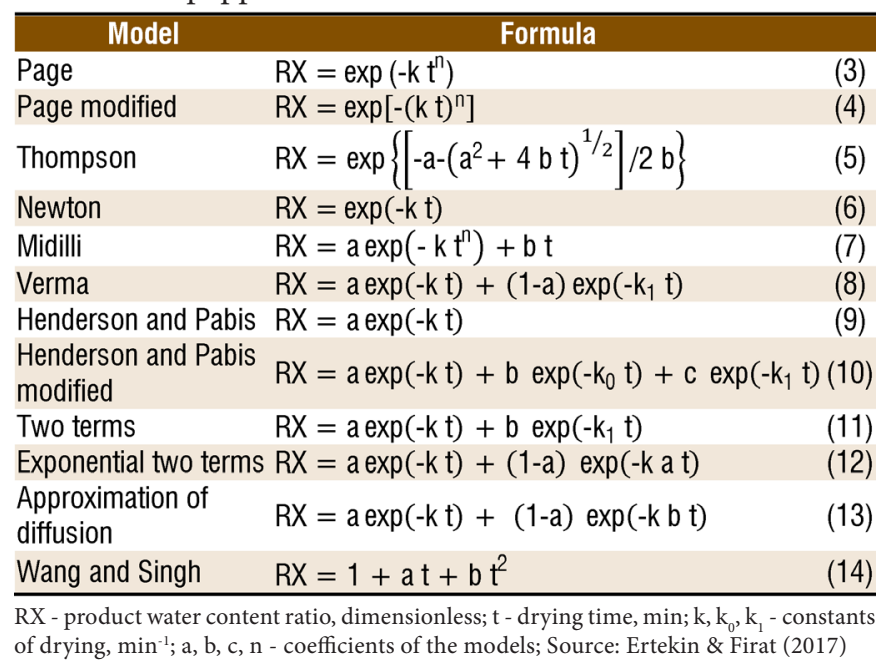


The Quasi-Newton method was used to estimate the parameters of the non-linear regression models. The fitted coefficient of determination $\left(\mathrm{R}^{2}\right)$, mean relative error $(\mathrm{P})$, mean estimated error (SE), and residue distribution (RD) were considered for the fit level analysis. P and SE were calculated according to the Eqs. 15 and 16:

$$
\begin{gathered}
\mathrm{P}=\frac{100}{\mathrm{n}} \sum_{\mathrm{i}=1}^{\mathrm{n}}\left(\frac{|\mathrm{Y}-\hat{\mathrm{Y}}|}{\mathrm{Y}}\right) \\
\mathrm{SE}=\sqrt{\frac{\sum_{\mathrm{i}=1}^{\mathrm{n}}(\mathrm{Y}-\hat{\mathrm{Y}})^{2}}{\mathrm{DF}}}
\end{gathered}
$$

where:

$\mathrm{P} \quad$ - mean relative error;

$\mathrm{n}$ - number of experimental observations;

Y - experimental value found;

$\hat{Y} \quad$ - estimated value by the model;

SE - mean estimated error; and,

DF - degrees of freedom of the model.

The consumed electric energy and specific energy consumption were calculated using Eq. 17 (Park et al., 2007) and 18 and the data were analyzed through correlation:

$$
\begin{gathered}
\mathrm{CEE}=\left[\left(\mathrm{F}_{\mathrm{air}} \rho_{\text {air }} \mathrm{Cp}_{\mathrm{air}} \Delta \mathrm{T}\right)+\mathrm{Ev}\right] \mathrm{t} \\
\mathrm{SEC}=\frac{3.6 \mathrm{CEE}}{\mathrm{w}_{\mathrm{ev}}}
\end{gathered}
$$

where:

CEE - consumed electric energy, kWh;

$\mathrm{F}_{\text {air }} \quad$ - air flow, $\mathrm{m}^{3} \mathrm{~s}^{-1}$;

$\rho_{\text {air }} \quad$ - air specific weight, $\mathrm{kg} \mathrm{m}^{-3}$;

$\mathrm{Cp}_{\text {air }}$ - air specific heat at constant pressure, $\mathrm{kJ} \mathrm{kg}^{-1}{ }^{\circ} \mathrm{C}$;

$\Delta \mathrm{T}$ - difference between environmental and drying air temperatures, ${ }^{\circ} \mathrm{C}$;

$\mathrm{Ev}$ - electric energy needed to move the fan, $\mathrm{kW}$;

$\mathrm{t}$ - dryer operation time, h;

SEC - specific energy consumption, $\mathrm{MJ} \mathrm{kg}^{-1}$; and,

$\mathrm{w}_{\mathrm{ev}}$ - evaporated water weight, $\mathrm{kg}$.

The Brazilian peppertree fruits were cleaned for removal of impurity and green fruits before the extraction of the essential oil, since the maturation stage affect the yield and quality of the essential oil (Schimitberger et al., 2018). The essential oil was extracted by hydro-distillation, in a Clevenger device, using $100 \mathrm{~g}$ of fruits for the dried whole fruits and $40 \mathrm{~g}$ for the dried fruits fragmented in a knife mill with a $2 \mathrm{~mm}$ mesh sieve (Fritsch Pulverisette 14, Oberstein, Germany).

The fruits were added to a volumetric flask containing 1000 $\mathrm{mL}$ of distilled water and this mixture was subjected to essential oil extraction for three hours from the beginning of ebullition.

The essential oil was then separated from the condensed water by subjecting the hydrolat to a partition process with
$20 \mathrm{~mL}$ of pentane p.a. for three times. Anhydrous sodium carbonate p.a. was added to the organic fraction (essential oil and pentane) to remove residual water. The solution was filtered and concentrated in a rotative evaporator at $40{ }^{\circ} \mathrm{C}$ under low pressure to obtain the pure essential oil. The essential oil yield was determined by weighing and expressed in percentage in relation to the dry matter (\% d.m.).

The essential oil yield as a function of drying air temperature was analyzed through regression analysis. The Tukey's test at $\mathrm{p} \leq 0.05$ was used to compare the means between the fruit fragmentation types.

\section{Results AND Discussion}

All models analyzed presented coefficient of determination $\left(\mathrm{R}^{2}\right)$ above $99 \%$, except the Wang and Singh model for the temperature of $50{ }^{\circ} \mathrm{C}$ (Table 2); however, the $\mathrm{R}^{2}$ is not an adequate index when used singly to select non-linear models. Thus, the model was satisfactory when presented value of $\mathrm{R}^{2}$ close to 100, P lower than 10\%, and low SE (Chen \& Morey, 1989; Madamba et al., 1996).

The Verma and Approximation of diffusion models had

\begin{tabular}{|c|c|c|c|c|c|}
\hline Model & $\begin{array}{c}\mathrm{T} \\
\left({ }^{\circ} \mathrm{C}\right)\end{array}$ & $\begin{array}{l}P \\
(\%)\end{array}$ & $\begin{array}{c}\text { SE } \\
\text { (decimal) }\end{array}$ & $\begin{array}{c}R^{2} \\
(\%)\end{array}$ & RD \\
\hline \multirow{3}{*}{ Page } & 50 & 4.355 & 0.012 & 99.791 & Tendentious \\
\hline & 60 & 3.497 & 0.012 & 99.830 & Tendentious \\
\hline & 70 & 1.592 & 0.005 & 99.976 & Random \\
\hline \multirow{3}{*}{ Page modified } & 50 & 4.355 & 0.012 & 99.791 & Tendentious \\
\hline & 60 & 3.498 & 0.012 & 99.830 & Tendentious \\
\hline & 70 & 1.592 & 0.005 & 99.976 & Random \\
\hline \multirow{3}{*}{ Thompson } & 50 & 2.853 & 0.008 & 99.904 & Tendentious \\
\hline & 60 & 2.785 & 0.009 & 99.896 & Tendentious \\
\hline & 70 & 1.887 & 0.009 & 99.926 & Tendentious \\
\hline \multirow{3}{*}{ Newton } & 50 & 8.860 & 0.023 & 99.241 & Tendentious \\
\hline & 60 & 5.109 & 0.015 & 99.685 & Tendentious \\
\hline & 70 & 1.889 & 0.008 & 99.926 & Tendentious \\
\hline \multirow{3}{*}{ Midilli } & 50 & 0.890 & 0.004 & 99.982 & Random \\
\hline & 60 & 1.014 & 0.003 & 99.987 & Random \\
\hline & 70 & 0.734 & 0.004 & 99.988 & Random \\
\hline \multirow{3}{*}{ Verma } & 50 & 0.869 & 0.004 & 99.981 & Random \\
\hline & 60 & 0.594 & 0.002 & 99.994 & Random \\
\hline & 70 & 1.889 & 0.009 & 99.926 & Tendentious \\
\hline \multirow{3}{*}{ Henderson and Pabis } & 50 & 7.602 & 0.020 & 99.425 & Tendentious \\
\hline & 60 & 4.841 & 0.015 & 99.715 & Tendentious \\
\hline & 70 & 1.709 & 0.007 & 99.944 & Tendentious \\
\hline \multirow{3}{*}{$\begin{array}{l}\text { Henderson and Pabis } \\
\text { modified }\end{array}$} & 50 & 0.933 & 0.004 & 99.982 & Random \\
\hline & 60 & 0.581 & 0.002 & 99.995 & Random \\
\hline & 70 & 1.709 & 0.011 & 99.944 & Tendentious \\
\hline \multirow{3}{*}{ Two-term } & 50 & 0.933 & 0.004 & 99.982 & Random \\
\hline & 60 & 0.598 & 0.002 & 99.994 & Random \\
\hline & 70 & 1.709 & 0.009 & 99.944 & Tendentious \\
\hline \multirow{3}{*}{ Two-term exponential } & 50 & 3.203 & 0.009 & 99.889 & Tendentious \\
\hline & 60 & 4.462 & 0.014 & 99.742 & Tendentious \\
\hline & 70 & 2.043 & 0.010 & 99.908 & Tendentious \\
\hline \multirow{3}{*}{$\begin{array}{l}\text { Approximation } \\
\text { of diffusion }\end{array}$} & 50 & 0.870 & 0.004 & 99.981 & Random \\
\hline & 60 & 0.594 & 0.002 & 99.994 & Random \\
\hline & 70 & 1.406 & 0.005 & 99.980 & Random \\
\hline \multirow{3}{*}{ Wang and Singh } & 50 & 10.006 & 0.031 & 98.597 & Tendentious \\
\hline & 60 & 5.212 & 0.019 & 99.536 & Tendentious \\
\hline & 70 & 3.158 & 0.010 & 99.890 & Tendentious \\
\hline
\end{tabular}
better fit for the temperatures of 50 and $60^{\circ} \mathrm{C}$; and the Midilli

Table 2. Statistic criteria for choice of mathematical model for the drying of Brazilian peppertree in each temperature

$\mathrm{T}$ - drying temperature; $\mathrm{P}$ - mean relative error; $\mathrm{SE}$ - mean estimated error; $\mathrm{R}^{2}$ - coefficient of determination; $\mathrm{RD}$ - residue distribution 
model had better fit for $70^{\circ} \mathrm{C}$. The models with better fit had the lowest mean estimated error and mean relative error lower than $5 \%$ for all temperatures. Silva et al. (2015) evaluated Brazilian peppertree fruits and found that the best model to describe the drying process was the Henderson; and the Wang and Singh was the least adequate.

Despite several models have adequate fit of the data, a model with satisfactory fit for all temperatures was chosen to facilitate its use, since modeling is used for drying simulations in thick layers and in the construction process of new dryers (Berbert et al., 1995; Goneli et al., 2014b; Gasparin et al., 2017). Therefore, the most adequate model was the Midilli. The result of $\mathrm{P}, \mathrm{SE}$, and $\mathrm{R}^{2}$ was acceptable, presenting random distribution of residues for all temperatures. This model was also adequate for the drying of leaves of Brazilian peppertree (Goneli et al., 2014b), rosemary (Mghazli et al., 2017) and timbo (Serjania marginata) (Martins et al., 2015) plants.

The increases in drying air temperature increased the $\mathrm{k}$ and $\mathrm{n}$ values; and the variables $\mathrm{a}$ and $\mathrm{b}$ presented no trend to the variations in temperature (Table 3 ).

The drying constant $\mathrm{k}$ of the Midilli model is related to the effective diffusivity in the decreasing period, which is similar to the Henderson and Pabis model (Ertekin \& Firat, 2017). The $\mathrm{k}$ value varies according to the drying air temperature and the product initial water content (Mujumdar \& Devahastin, 2000). The Brazilian peppertree fruits had no variation in initial water content; thus, the temperature affected the $k$ value. No trend was found for $a$ and $b$; the variations were related to mathematical adjustments of the model and not to the drying process (Goneli et al., 2014b).

The drying process occurred with decreasing rates (Figure 1 ); the resistance to migration of water from the interior to the surface of the product increased as it was drying (Park et al., 2001). The product temperature tends to increase in this stage up to temperatures close to that of the drying air. Studies with several medicinal plants also found drying curves with decreasing rates (Martinazzo et al., 2010; Ali et al., 2014; Gasparin et al., 2017; Mghazli et al., 2017).

Figure 2 shows the drying rate in the first $30 \mathrm{~min}$ of the process and confirms the increase in resistance of migration of water from the interior to the surface of the product as it was drying.

The increases in drying air temperature increased the drying rate, since a higher water removal from the product was found, agreeing with several researchers (Martins et al., 2015; Gasparin et al., 2017; Mghazli et al., 2017). A higher inclination of the line was found for the $70{ }^{\circ} \mathrm{C}$, indicating a higher variation in the drying rate, making the product to faster reach the water content desired than the other temperatures.

Table 3. Coefficients of the Midilli model for each drying air temperature

\begin{tabular}{|cccc|}
\hline Coefficients & \multicolumn{3}{c|}{ Temperature $\left({ }^{\circ} \mathrm{C}\right)$} \\
\cline { 2 - 4 } of the model & $\mathbf{5 0}$ & $\mathbf{6 0}$ & $\mathbf{7 0}$ \\
\hline $\mathrm{k}$ & 0.026003 & 0.028339 & 0.037470 \\
$\mathrm{n}$ & 0.993336 & 1.044275 & 1.076749 \\
$\mathrm{a}$ & 0.997523 & 0.998492 & 0.998579 \\
$\mathrm{~b}$ & 0.000575 & 0.000872 & 0.000475 \\
\hline
\end{tabular}

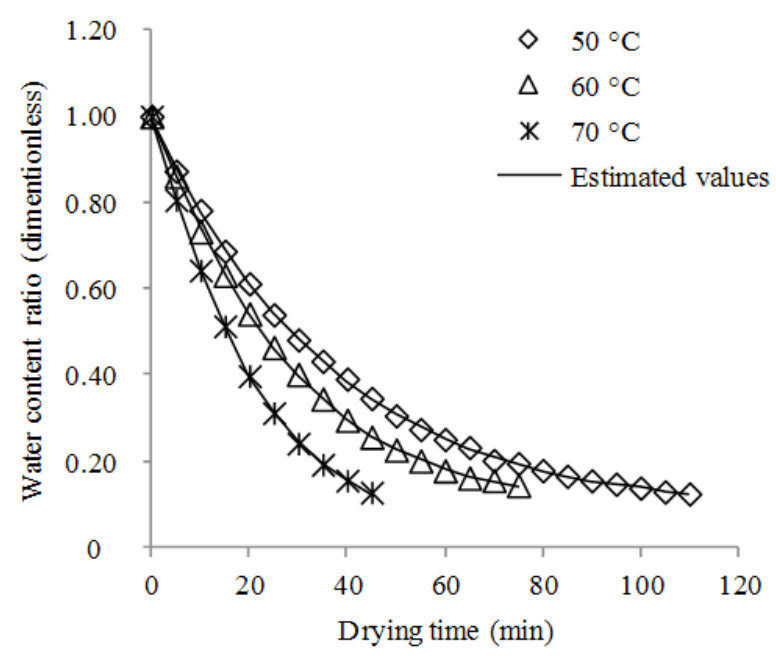

Figure 1. Water content ratio observed and estimated as a function of drying time by the Midilli model in three drying air temperatures

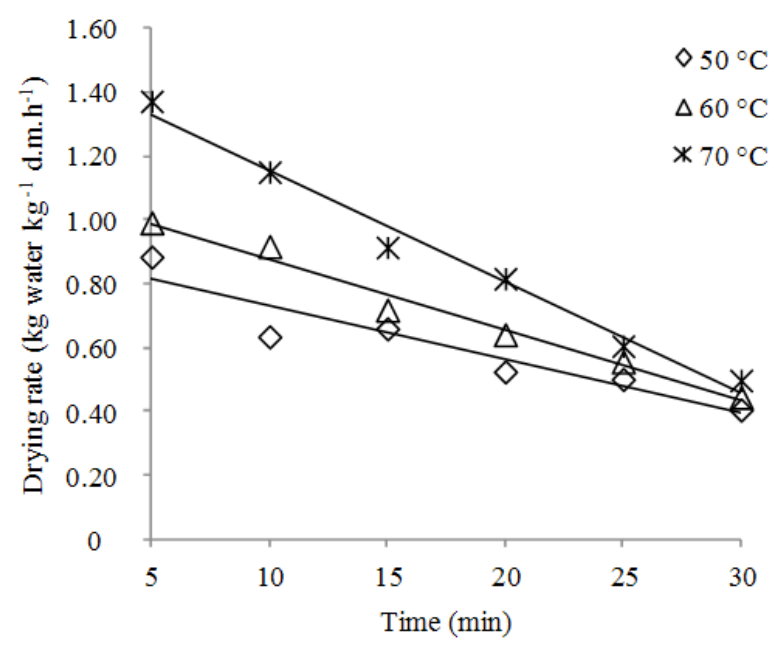

Figure 2. Variation in the drying rate of Brazilian peppertree fruits as a function of drying air temperature

The effects of temperature on the drying time, specific energy consumption, and consumed electric energy are shown in Table 4.

The increase in drying air temperature from 50 to $70{ }^{\circ} \mathrm{C}$ decreased the drying time in approximately $59 \%$, since higher temperatures result in higher water removal rates. This was also found for Mentha piperita (Gasparin et al., 2017) and Cordia verbenacea (Goneli et al., 2014a). The specific energy consumption decreased as the drying air temperature was increased, i.e., less energy was required to evaporate the same quantity of water from the Brazilian peppertree fruits when the drying air temperature was $70^{\circ} \mathrm{C}$, when compared to that at $50^{\circ} \mathrm{C}$.

Despite the dryer demands more energy when using a drying air temperature of $70{ }^{\circ} \mathrm{C}$, the drying time in this temperature is lower than that in $50{ }^{\circ} \mathrm{C}$, under the same environmental conditions, and it decreased the energy consumption.

The energy consumption of the drying operations can reach $40 \%$ of the total energy consumption of the industry, becoming a very expensive operation (Mujumdar \& Devahastin, 2000). Therefore, increasing drying air temperature can significantly decrease the operational cost of this process. 
Table 4. Mean and standard deviation of drying time, specific energy consumption, and consumed electric energy as a function of drying air temperature

\begin{tabular}{|c|ccc|}
\hline $\begin{array}{c}\text { Drying air temperature } \\
\left({ }^{\circ} \mathbf{C}\right)\end{array}$ & $\begin{array}{c}\text { Drying time } \\
(\mathbf{m i n})\end{array}$ & $\begin{array}{c}\text { Specific energy consumption } \\
\left(\mathbf{M J ~ k g}^{-1}\right)\end{array}$ & $\begin{array}{c}\text { Consumed electric energy } \\
(\mathbf{k W h})\end{array}$ \\
\hline 50 & $108.33 \pm 2.89$ & $112.63 \pm 2.74$ & $3.44 \pm 0.09$ \\
60 & $71.67 \pm 5.77$ & $98.47 \pm 7.84$ & $3.02 \pm 0.24$ \\
70 & $45.00 \pm 0$ & $73.65 \pm 0.62$ & $2.27 \pm 0$ \\
\hline
\end{tabular}

The correlations between drying air temperature and the other variables were significant $(\mathrm{p} \leq 0.05)$. Temperature presented negative correlation with drying time (-0.98), specific energy consumption (-0.95), and consumed electric energy (-0.95). Therefore, increasing drying air temperature tends to decrease other variables. This effect had been found for several agricultural products, such as rosemary, rice, and chrysanthemum (Mghazli et al., 2017; Tohidi et al., 2017; Wang et al., 2018).

According to the analysis of variance, the interaction between drying air temperature and fruit fragmentation was significant by the $\mathrm{F}$ test ( $\mathrm{p}$-value $=0.0163$ ) for essential oil yield; therefore, these factors have dependent effect on essential oil yield.

Figure 3 shows the mean essential oil yield as a function of drying air temperature and fruit fragmentation.

The essential oil yield from whole fruits of Brazilian peppertree was maintained as the drying air temperature increased, but decreased linearly $(p$-value $=0.0037)$ for fragmented fruits.

Essential oils are substances sensitive to heat; therefore, increasing drying air temperature can volatilize these compounds (Ebadi et al., 2015; Ahmed et al., 2018). Differences in yield due to temperatures were not found for whole fruits, since the exocarp hindered the extraction of essential oil (Machado \& Carmello-Guerreiro, 2001).

The essential oil yield of the fragmented Brazilian peppertree fruits was approximately 26-, 23-, and 18-fold those obtained with whole fruits for the drying air temperature of 50,60 , and $70{ }^{\circ} \mathrm{C}$, respectively.

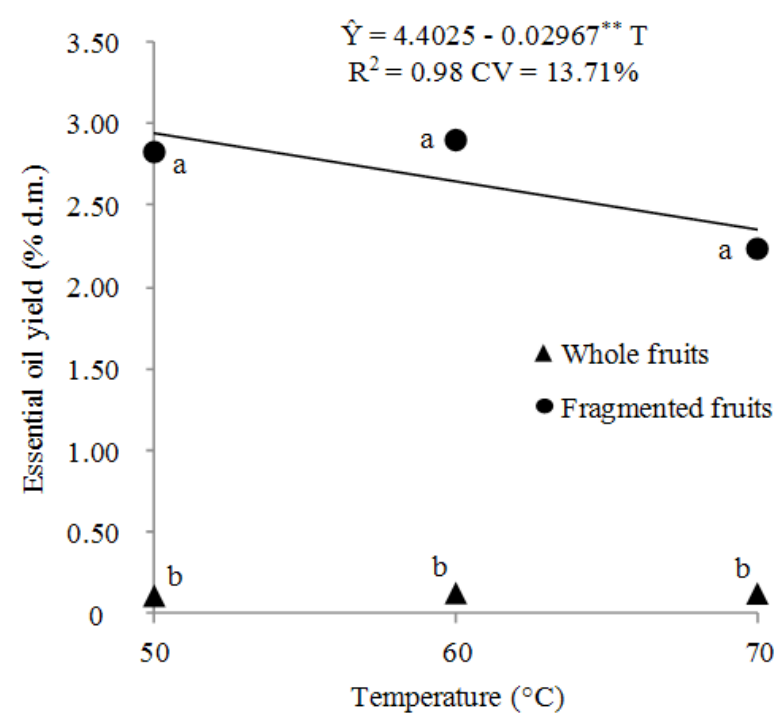

Means followed by same letter for same temperature are not different by the Tukey's test at $\mathrm{p} \leq 0.05$; Regression equation referring to fragmented fruits; $\mathrm{CV}$ - coefficient of variation; " - Significant at $\mathrm{p} \leq 0.01$ by t test

Figure 3. Brazilian peppertree fruit essential oil yield as a function of drying temperature and fruit fragmentation
This may be due to the well-developed and complex secretor channels of the Brazilian peppertree seeds, which are protected by the exocarp (Machado \& Carmello-Guerreiro, 2001). Thus, the fragmentation facilitated the extraction of essential oil, since it had exposed structures that contained the essential oil and increased the contact surface of the fruits with the water used in the hydro-distillation.

Schimitberger et al. (2018) found similar essential oil yield for fragmented Brazilian peppertree fruits. However, Oliveira Junior et al. (2013) found yields varying from 5.50 to $8.41 \%$. This difference is not related only to the drying process, but to edaphoclimatic factors and factors inherent to the plants, which can affect secondary metabolites, such as water availability, and plant development (Gobbo-Neto \& Lopes, 2007).

Ahmed et al. (2018) and Schimitberger et al. (2018) evaluated visually the color of essential oil obtained. The color of the essential oil was also affected by the fruit fragmentation. Visually, the essential oil extracted from whole fruits was yellowish and that of the fragmented fruits was translucid; this indicates differences in their chemical composition.

\section{Conclusions}

1. The Midilli model was the most adequate to describe the drying process of Brazilian peppertree fruits for all temperatures studied.

2. The drying air temperature of $70{ }^{\circ} \mathrm{C}$ decreased the drying time, consumed electric energy, and specific energy consumption.

3. The highest essential oil yield of Brazilian peppertree was found for the drying temperature of $50^{\circ} \mathrm{C}$ and for fragmented fruits after the drying process.

\section{ACKNOWLedgements}

This study was financed in part by the Conselho Nacional de Desenvolvimento Científico e Tecnológico - Brasil (CNPq), Coordenação de Aperfeiçoamento de Pessoal de Nível Superior - Brasil (CAPES) - Finance code 001, and Fundação de Amparo à Pesquisa do Estado de Minas Gerais (FAPEMIG). The authors thank the Universidade Federal de Viçosa, and the AgroRosa Company for providing the Brazilian peppertree fruits for this study.

\section{Literature Cited}

Ahmed, A.; Ayoub, K.; Chaima, A. J.; Hanaa, L.; Abdelaziz, C. Effect of drying methods on yield, chemical composition and bioactivities of essential oil obtained from Moroccan Mentha pulegium L. Biocatalysis and Agricultural Biotechnology, v.16, p.638-643, 2018. https://doi.org/10.1016/j.bcab.2018.10.016 
Ali, M. A.; Yusof, Y. A.; Chin, N. L.; Ibrahim, M. N.; Basra, S. M. A. Drying kinetics and colour analysis of Moringa oleifera leaves. Agriculture and Agricultural Science Procedia, v.2, p. 94400, 2014. https://doi.org/10.1016/j.aaspro.2014.11.055

ANVISA - Agência Nacional de Vigilância Sanitária. Farmacopeia brasileira, 5.ed. Brasília: ANVISA, 2010. 546p.

Berbert, P. A.; Queiroz, D. M. de; Silva, J. S.; Pinheiro Filho, J. B. Simulation of coffee drying in a fixed bed with periodic airflow reversal. Journal of Agricultural Engineering Research, v.60, p.167-173, 1995. https://doi.org/10.1006/jaer.1995.1010

Borsato, A. V.; Doni-Filho, L.; Paglia, E. C. Tricomas glandulares e teores de água e de óleo essencial da camomila [Chamomilla recutita (L.) Rauschert] sob secagem em camada fina. Revista Brasileira de Plantas Medicinais, v.10, p.50-55, 2008.

Castro, A. M.; Mayorga, E. Y.; Moreno, F. L. Mathematical modelling of convective drying of fruits: A review. Journal of Food Engineering, v.223, p.152-167, 2018. https://doi.org/10.1016/j. jfoodeng.2017.12.012

Cavalcanti, A. doa S.; Alves, M. de S.; Silva, L. C. P. da; Patrocínio, D. dos S.; Sanches, M. N.; Chaves, D. S. de A.; Souza, M. A. A. de. Volatiles composition and extraction kinetics from Schinus terebinthifolius and Schinus molle leaves and fruit. Revista Brasileira de Farmacognosia, v.25, p.356-362, 2015. https://doi. org/10.1016/j.bjp.2015.07.003

Chen, C.; Morey, R. V. Comparison of four EMC/ERH equations. Transactions of the ASAE, v.32, p.983-990, 1989. https://doi.org/10.13031/2013.31103

Dannenberg, G. S.; Funck, G. D.; Mattei, F. J.; Silva, V. P.; Fiorentini, A. M. Antimicrobial and antioxidant activity of essential oil from pink pepper tree (Schinus terebinthifolius Raddi) in vitro and in cheese experimentally contaminated with Listeria monocytogenes. Innovative Food Science and Emerging Technologies, v.36, p.120127, 2016. https://doi.org/10.1016/j.ifset.2016.06.009

Ebadi, M. T.; Azizi, M.; Sefidkon, F.; Ahmadi, N. Influence of different drying methods on drying period, essential oil content and composition of Lippia citriodora Kunth. Journal of Applied Research on Medicinal and Aromatic Plants, v.2, p.182-187, 2015. https://doi.org/10.1016/j.jarmap.2015.06.001

Ertekin, C.; Firat, M. Z. A comprehensive review of thin-layer drying models used in agricultural products. Critical Reviews in Food Science and Nutrition, v.57, p.701-717, 2017. https://doi.org/10. 1080/10408398.2014.910493

Gasparin, P. P.; Alves, N. C. C.; Coelho, S. R. M. Qualidade de folhas e rendimento de óleo essencial em hortelã pimenta (Mentha $x$ piperita L.) submetida ao processo de secagem em secador de leito fixo. Revista Brasileira de Plantas Medicinais, v.16, p.337-344, 2014. https://doi.org/10.1590/1983-084X/12_003

Gasparin, P. P.; Christ, D.; Coelho, S. R. M. Secagem de folhas Mentha piperita em leito fixo utilizando diferentes temperaturas e velocidades de ar. Revista Ciência Agronômica, v.48, p.242250, 2017.

Gobbo-Neto, L.; Lopes, N. P. Plantas medicinais: Fatores de influência no conteúdo de metabólitos secundários. Química Nova, v.30, p.374-381, 2007. https://doi.org/10.1590/S010040422007000200026

Goneli, A. L. D.; Nasu, A. K.; Gancedo, R.; Araújo, W. D.; Sarath, K. L. L. Cinética de secagem de folhas de erva baleeira (Cordia verbenacea DC.). Revista Brasileira de Plantas Medicinais, v.16, p.434-443, 2014a. https://doi.org/10.1590/1983-084X/13_041
Goneli, A. L. D.; Vieira, M. C.; Vilhasanti, H. C. B.; Gonçalves, A. A. Modelagem matemática e difusividade efetiva de folhas de aroeira durante a secagem. Pesquisa Agropecuária Tropical, v.44, p.56-64, 2014b. https://doi.org/10.1590/S198340632014000100005

Machado, S. R.; Carmello-Guerreiro, S. M. Estrutura e desenvolvimento de canais secretores em frutos de Schinus terebinthifolius Raddi (Anacardiaceae). Acta Botanica Brasilica, v.15, p.189-195, 2001. https://doi.org/10.1590/S010233062001000200005

Madamba, P. S.; Driscoll, R. H.; Buckle, K. A. The thin-layer drying characteristics of garlic slices. Journal of Food Engineering, v.29, p.75-97, 1996. https://doi.org/10.1016/0260-8774(95)00062-3

Martinazzo, A. P.; Melo, E. C.; Corrêa, P. C.; Santos, R. H. S. Modelagem matemática e parâmetros qualitativos da secagem de folhas de capim-limão [Cymbopogon citratus (DC.) Stap]. Revista Brasileira de Plantas Medicinais, v.12, p.488-498, 2010. https:// doi.org/10.1590/S1516-05722010000400013

Martins, E. A. S.; Lage, E. Z.; Goneli, A. L. D.; Hartmann Filho, C. P.; Lopes, J. G. Cinética de secagem de folhas de timbó (Serjania marginata Casar). Revista Brasileira de Engenharia Agrícola e Ambiental, v.19, p.238-244, 2015. https://doi.org/10.1590/18071929/agriambi.v19n3p238-244

Melo, E. C.; Lopes, D. C.; Côrrea, P. C. GRAPSI - Programa computacional para o cálculo das propriedades psicrométricas do ar. Engenharia na Agricultura, v.12, p.154-162, 2004.

Memarzadeh, S. M.; Pirbalouti, A. G.; Adibnejad, M.. Chemical composition and yield of essential oils from Bakhtiari savory (Satureja bachtiarica Bunge.) under different extraction methods. Industrial Crops and Products, v.76, p.809-816, 2015. https://doi.org/10.1016/j.indcrop.2015.07.068

Mghazli, S.; Ouhammou M.; Hidar, N.; Lahnine, L.; Idlimam, A.; Mahrouz, M. Drying characteristics and kinetics solar drying of Moroccan rosemary leaves. Renewable Energy, v.108, p.303-310, 2017. https://doi.org/10.1016/j.renene.2017.02.022

Mujumdar, A. S.; Devahastin, S. Fundamental principles of drying. In: Devahastin, S. (ed.). Mujumdar's practical guide to industrial drying: Principles, equipment and new developments. Montreal: Exergex Corporation, 2000. Cap. 1, p.1-22.

Oliveira Junior, L. F. G.; Santos, R. B.; Reis, F. O.; Matsumoto, S. T.; Bispo, W. M. S.; Machado, L. P.; Oliveira, L. F. M. Efeito fungitóxico do óleo essencial de aroeira da praia (Schinus terebinthifolius RADDI) sobre Colletotrichum gloeosporioides. Revista Brasileira de Plantas Medicinais, v.15, p.150-157, 2013. https://doi. org/10.1590/S1516-05722013000100021

Park, K. J.; Antonio, G. C.; Oliveira, R. D.; Park, K. J. B. Conceitos de processo e equipamentos de secagem. Campinas: Unicamp, 2007.

Park, K. J.; Yado, M. K. M.; Brod, F. P. R. Estudo de secagem de pêra bartlett (Pyrus sp.) em fatias. Ciência e Tecnologia de Alimentos, v.21, p.288-292, 2001. https://doi.org/10.1590/S010120612001000300007

Rosado, L. D. S.; Pinto, J. E. B. P.; Botrel, P. P.; Bertolucci, S. K. V.; Niculau, E. S.; Alves, P. B. Influência do processamento da folha e tipo de secagem no teor e composição química do óleo essencial de manjericão cv. Maria Bonita. Ciência e Agrotecnologia, v.35, p.291-296, 2011. https://doi.org/10.1590/ S1413-70542011000200009 
Rosas, E. C.; Correa, L. B.; Pádua, T. de A.; Costa, T. E. M. M; Mazzei, J. L.; Heringer, A. P.; Bizarro, C. A.; Kaplan, M. A. C.; Figueiredo, M. R.; Henriques, M. G. Anti-inflammatory effect of Schinus terebinthifolius Raddi hydroalcoholic extract on neutrophil migration in zymosaninduced arthritis. Journal of Ethnopharmacology, v.175, p.490-498, 2015. https://doi.org/10.1016/j.jep.2015.10.014

Schimitberger, V. M. B.; Pratti, D. L. A.; Cavalcanti, L. C.; Ramalho, V. F.; Costa, A. P. F.; Scherer, R.; Kuster, R. M.; Ramos, A. C.; Silva, A. G. Volatile compounds profile changes from unripe to ripe fruits of Brazilian pepper (Schinus terenthifolia Raddi). Industrial Crops and Products, v.119, p.125131, 2018. https://doi.org/10.1016/j.indcrop.2018.04.011

Silva, B. G. da; Fileti, A. M. F.; Taranto, O. P. Drying of Brazilian pepper-tree fruits (Schinus terebinthifolius Raddi): Development of classical models and artificial neural network approach. Chemical Engineering Communications, v.202, p.1089-1097, 2015. https:// doi.org/10.1080/00986445.2014.901220
Tohidi, M.; Sadeghi, M.; Torki-Harchegani, M. Energy and quality aspects for fixed deep bed drying of paddy. Renewable and Sustainable Energy Reviews, v.70, p.519-528, 2017. https://doi. org/10.1016/j.rser.2016.11.196

Vinatoru, M. An overview of the ultrasonically assisted extraction of bioactive principles from herbs. Ultrasonics sonochemistry, v.8, p.303-313, 2001. https://doi.org/10.1016/ S1350-4177(01)00071-2

Wang, Y.; Li, X.; Chen, X.; Li, B.; Mao, X.; Miao, J.; Zhao, C.; Huang, L.; Gao, W. Effects of hot air and microwave-assisted drying on drying kinetics, physicochemical properties, and energy consumption of chrysanthemum. Chemical Engineering and Processing - Process Intensification, v.129, p.84-94, 2018. https://doi.org/10.1016/j. cep.2018.03.020 